Article

\title{
Life Cycle Analysis of Strengthening Existing RC Structures with R-PE-UHPFRC
}

\author{
Amir Hajiesmaeili ${ }^{1, *(0)}$, Francesco Pittau ${ }^{2}\left(0\right.$, Emmanuel Denarié $^{1}$ and Guillaume Habert ${ }^{2}(\mathbb{C}$ \\ 1 Maintenance and Safety of Structures, Ecole Polytechnique Fédérale de Lausanne, CH-1015 Lausanne, \\ Switzerland; emmanuel.denarie@epfl.ch \\ 2 Institute of Construction and Infrastructure Management, Swiss Federal Institute of Technology Zurich (ETH \\ Zurich), CH-8093 Zurich, Switzerland; pittau@ibi.baug.ethz.ch (F.P.); habert@ibi.baug.ethz.ch (G.H.) \\ * Correspondence: amir.hajiesmaeili@epfl.ch
}

Received: 7 November 2019; Accepted: 1 December 2019; Published: 5 December 2019

check for updates

\begin{abstract}
PE)-UHPFRC, a novel strain hardening ultra high-performance fiber reinforced concrete (UHPFRC) with low clinker content, using Ultra-High Molecular Weight Polyethylene (UHMW-PE) fibers, was developed for structural applications of rehabilitation. A comprehensive life cycle assessment (LCA) was carried out to study the environmental impact of interventions on an existing bridge using PE-UHPFRC compared with conventional UHPFRC and post-tensioned reinforced concrete methods in three categories of global warming potential (GWP), cumulative energy demand (CED), and ecological scarcity (UBP). The results showed $55 \%$ and $29 \%$ decreases in the environmental impact of the PE-UHPFRC compared with reinforced concrete and conventional UHPFRC methods, respectively, which highlighted the effectiveness of this material for the rehabilitation/strengthening of structures from the viewpoint of environmental impact.
\end{abstract}

Keywords: UHPFRC; LCA; sustainability; UHMW-PE fibers; rehabilitation; strengthening

\section{Introduction}

Over the last few decades, the aging of transportation infrastructure systems has become an acute societal issue, and rehabilitation and strengthening of existing structures now prevail over new construction. Considering Figure 1, which shows the number of commissioned bridges per five years in Switzerland, it can be predicted that the need for rehabilitation of bridges that were constructed in the period 1960-1980, with a planned service life of 50 years, will result in the near future in a much higher demand on resources and funding. A similar scenario takes place in most developed countries that developed their infrastructures between the 1960s and the 1980s. Material consumption and environmental issues of construction sites are heavy burdens for society in terms of economy and environment [1-3]. Thus, developing reliable and more efficient strategies and technologies of construction works are essential in order to meet the needs of the present without compromising the ability of future generations to meet their own needs [4], which is the concept of sustainable development. 


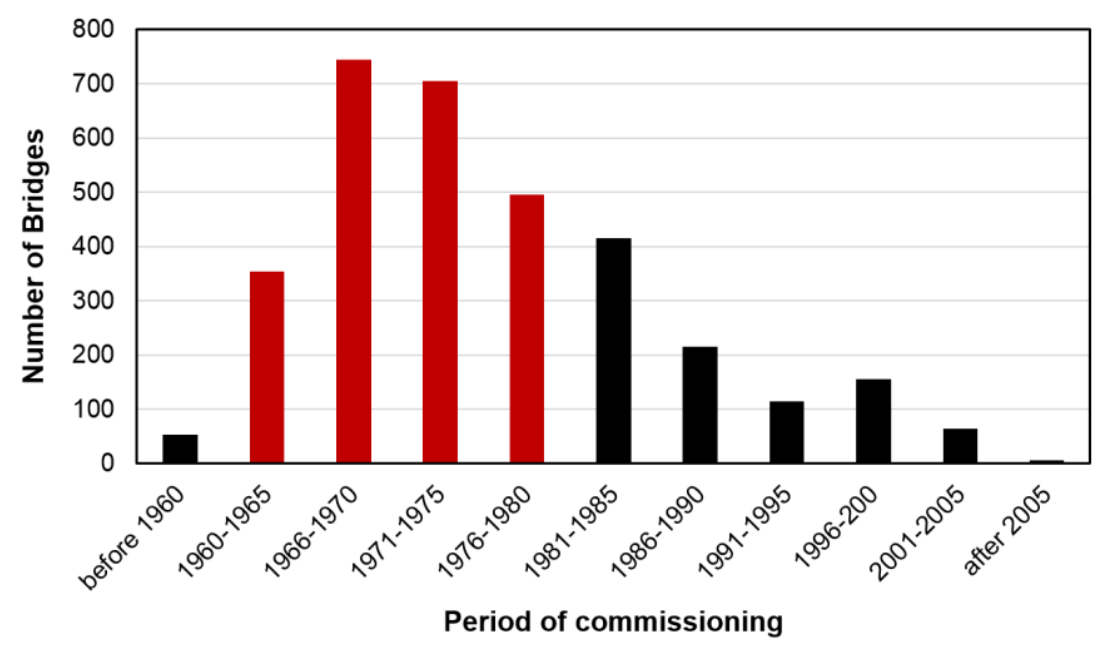

Figure 1. Number of commissioned bridges per five years in Switzerland [5].

Ultra high-performance fiber reinforced concrete (UHPFRC) is a cementitious materials with a very dense matrix, reinforced with discontinuous fibers, which typically have a compressive strength of $150-200 \mathrm{MPa}$, a tensile strength of 7-15 MPa, a strain hardening domain of $1 \%$ o- $2 \%$, and a very low water capillary absorption, typically five times smaller than that of concretes prescribed for severe exposure classes (XD3/XF4). The concept of rehabilitation and strengthening of existing bridges with UHPFRC for the whole service life of the bridge was proposed by Brühwiler in 1999 after the pioneering works of Bache et al. [6]. The basic idea was the efficient use, as an "everlasting winter coat", of a thin UHPFRC overlay in zones of severe mechanical and environmental exposure where the outstanding UHPFRC properties, in terms of durability and strength, could be exploited effectively with the UHPFRC alone or could be associated with rebar for strengthening applications. This idea was successfully implemented for the rehabilitation and strengthening of road and railway infrastructures, as well as buildings, for over 15 years and was extended to marine structures by Denarié [7-9].

Starting in 2007, Denarié et al. [10] developed, for the first time, Eco-UHPFRC mixes with the extensive use of limestone filler in place of clinker. These tensile strain hardening UHPFRC mixes were applied successfully at an industrial scale, first to the rehabilitation of the Log Čezsoški bridge in Slovenia [11] (mix based mostly on local components), and later in Switzerland (also mostly using local components) for numerous rehabilitation sites, including thixotropic mixes applicable on slopes up to $12 \%$ [12].

Habert et al. [13] performed a life cycle analysis of the Log Čezsoški application in Slovenia, highlighting the significant improvements brought by low clinker mixes to the reduction of the global warming potential (GWP). Rehabilitation methods using UHPFRC already decrease the environmental impact of construction sites by up to 50\% [13] and considerably reduce the construction time compared to conventional methods. However, there is still potential to improve this method even further and make it more sustainable, focusing on the environmental cost of clinker and fibrous mixes used to achieve a robust strain hardening response. Considering the fact that more than $95 \%$ of the environmental impact (GWP and embodied energy) of current UHPFRC is from the steel fibers and clinker contributions (48\% and $47 \%$, respectively for GWP) [14,15], replacing the steel fibers with synthetic ones while also replacing clinker with Supplementary Cementitious Materials (SCM), can significantly reduce the environmental costs of this material.

Polyethylene (PE)-UHPFRC is a newly developed UHPFRC mix in which the steel fibers are replaced with ultra-high molecular weight polyethylene (UHMW-PE) ones, and $50 \%$ of the clinker is replaced with limestone fillers [16]. The high tensile elastic limit above $7 \mathrm{MPa}$, the tensile strength of more than $10 \mathrm{MPa}$, and the tensile deformation capacity of more than 3.5\% make PE-UHPFRC well adapted for structural applications. This newly developed material has the potential to strongly 
decrease the environmental impact of the UHPFRC rehabilitation/strengthening method. Additionally, the dead weight of PE fiber based UHPFRC mixes is significantly reduced compared to that of conventional UHPFRC that use steel fibers (thanks to the 10 to 20 times reduction in the mass of the fibrous mix for comparable tensile properties).

The present study reports on the properties and advantages of a new strain hardening UHPFRC mix with synthetic PE fibers and reduced clinker content adapted for structural applications, in terms of the consequences on reducing environmental burdens. In the first step, the properties of the material are presented. Secondly, the life cycle assessment (LCA) method [17-20] is described, explaining the functional unit and the inventory data for this study. Finally, the environmental impact of three types of intervention on an existing bridge, including (1) demolition and reconstruction with post-tensioned reinforced concrete, (2) strengthening with steel fiber UHPFRC combined with rebar, and (3) strengthening with PE-UHPFRC combined with rebar are evaluated in three categories of GWP, cumulative energy demand (CED), and ecological scarcity (UBP).

\section{Mix Design and Properties of PE-UHPFRC}

In the newly developed PE-UHPFRC mix, the steel fibers were fully replaced by UHMW-PE ones, and $50 \%$ volume of the clinker was replaced by two limestone fillers of different grades (OMYA Betocarb ${ }^{\circledR}-$ HP SL and Betoflow $\left.{ }^{\circledR}-D\right)$. The composition of the mix is given in Table 1. The fibrous mix consisted of $2 \%$ vol. $6 \mathrm{~mm}$ long, chopped UHMW-PE fiber type SK 99 from DSM Dyneema ${ }^{\circledR}$. $\mathrm{Ca}\left(\mathrm{NO}_{3}\right)_{2}$ was added to improve the efficiency of the High-Range Water-Reducing Admixture (HRWRA) in order to decrease its dosage.

Typical properties of PE-UHPFRC are presented in Table 2. The results are the average of fifteen dumbbell specimens based on [21] for the tensile properties, three cylinders based on [22] for compressive strength, and six specimens based on [23] for the capillary absorption coefficient, all at 28 days. Furthermore, at the fresh state, the air content and the specific weight of the material were $4.5 \%$ and $2215 \mathrm{~kg} / \mathrm{m}^{3}$, respectively, and the flow was $48 \%$ after ASTM C1437 [24], with a final diameter after 25 blows of $150 \mathrm{~mm}$.

Table 1. Mix proportions of the polyethylene-ultra high-performance fiber reinforced concrete (PE-UHPFRC) (Mix PE21).

\begin{tabular}{ll}
\hline Components & $\mathbf{( \mathbf { k g } / \mathbf { m } ^ { \mathbf { 3 } } \mathbf { ) }}$ \\
\hline Cement CEM I 52.5 HTS & 508 \\
Silica fume & 178 \\
Betocarb $^{\circledR}$ - HP SL & 170 \\
Betoflow $^{\circledR}$-D & 389 \\
Fine sand $\left(\mathrm{d}_{50}=250 \mu \mathrm{m}\right)$ & 525 \\
Quartz powder & 223 \\
Water & 165 \\
HRWRA & 27 \\
Ca(NO $\left.{ }_{3}\right)_{2}$ & 11 \\
UHMW PE fibers (Dyneema ${ }^{\circledR}$ SK99) & 19.6 \\
\hline
\end{tabular}

Table 2. Properties of PE-UHPFRC, average (standard deviation).

\begin{tabular}{ll}
\hline Properties & PE-UHPFRC \\
\hline Tensile strength $(\mathrm{MPa})$ & $11.7(0.6)$ \\
Tensile elastic limit $(\mathrm{MPa})$ & $7.7(0.5)$ \\
Tensile strain at peak stress $(\%$ ) & $35(10)$ \\
Compressive strength $(\mathrm{MPa})$ & $120(2.6)$ \\
Young's modulus $(\mathrm{Gpa})$ & $42.6(2.2)$ \\
Sorptivity $\left(\mathrm{g} / \mathrm{m}^{2} \sqrt{\mathrm{h}}\right)$ & $24(3)$ \\
Specific weight $\left(\mathrm{kg} / \mathrm{m}^{3}\right)$ & $2215(22)$ \\
\hline
\end{tabular}




\section{Environmental Evaluation Method}

\subsection{Function Unit and System Boundaries}

In this study, the LCA method, based on ISO14040 [25], was chosen to perform an environmental evaluation and investigate the impact of the newly developed material with respect to other ones. As the alternative materials do not all have similar mechanical and durability properties compared with that of PE-UHPFRC, it was not sufficient to benchmark these materials per unit volume. Thus, different structural solutions with comparable performances in terms of protective function and load carrying capacity were compared and, finally, opportunities to improve the environmental performance of the current techniques were identified. The functional unit was an intervention on the Guillermaux Bridge (restoration or replacement) that was built in 1920/21 in Payerne, Switzerland [26]. The original bridge structure was a massive reinforced concrete arch (span $34 \mathrm{~m}$ ) with three hinges (at the arch crown and the two abutments) that carried a $6.5 \mathrm{~m}$ wide bi-directional roadway and sidewalks (10 $\mathrm{m}$ width in total). The Guillermaux Bridge, its arc, and hinges before intervention are shown in Figure 2.

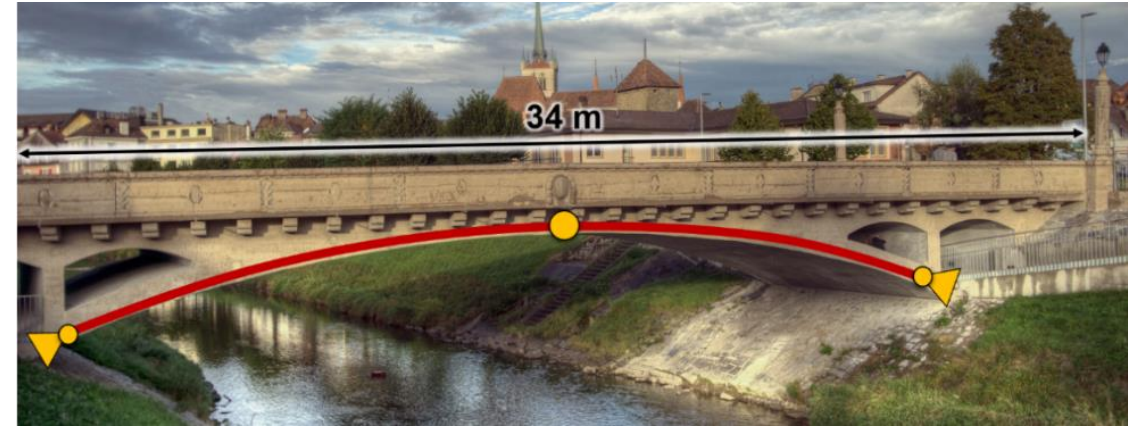

(a)

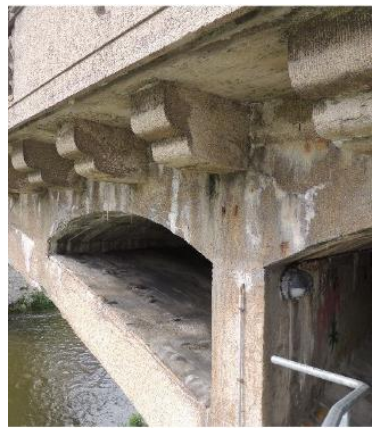

(b)

Figure 2. The Guillermaux Bridge, its arc, and hinges before intervention (a) and the signs of water infiltration, leachates, and corrosion on the bridge (b).

As the surface of the bridge was never protected with waterproofing, the concrete of the bridge structure showed signs of water infiltration, leachates, and corrosion. The requirement of utilization after the restoration was unrestricted road traffic (after SIA 269/1 load models) including specially authorized exceptionally heavy vehicles. The environmental impact of three different methods that provide the same functions was compared:

(1) Method 1 involves demolition of the existing structure and construction of a new post-tensioned reinforced concrete (P-RC) bridge. For this scenario, the design from [27] of a new bridge with multiple T-section post-tensioned girders is used, with the span and width corresponding to the existing structure in which the requirements for the clearance to the water level of the river below are fulfilled. It is assumed that ready-mixed concrete will be transported and placed on site for construction of the bridge. Figure 3 shows the cross-section of the new structure [27].

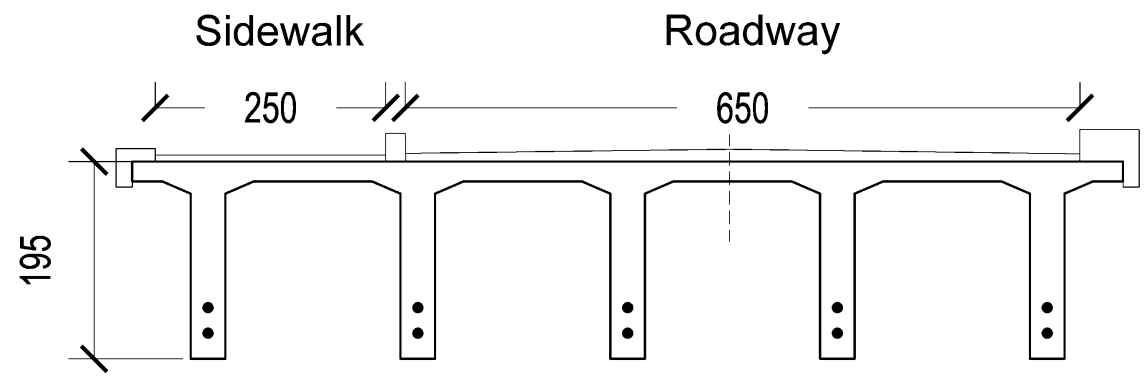

Figure 3. Cross section of post-tensioned girders (all dimensions in cm), Method 1. 
(2) Method 2 involves strengthening the existing bridge with the help of steel fiber UHPFRC (S-UHPFRC) with rebar. In this method, a $40 \mathrm{~mm}$ thick layer of reinforced UHPFRC is cast over the entire length of the bridge's top surface and on the deck and internal faces of curbs, and is fixed at both extremities by new transition slabs anchored in the ground in order to provide an Reinforced UHPFRC (R-UHPFRC) tensile membrane. Furthermore, the hinge at the arch crown is locked using reinforced concrete so as to allow for bending resistance. Figure 4 depicts the details of this method. The new static system is based on: (1) A locking central hinge and (2) a tensile ribbon with R-UHPFRC anchored in the transition slabs of the abutments. The UHPFRC and the rebar carry the traffic loads together after the intervention, and the design stress in the UHPFRC at ultimate limit state (ULS) is 7.6 MPa.

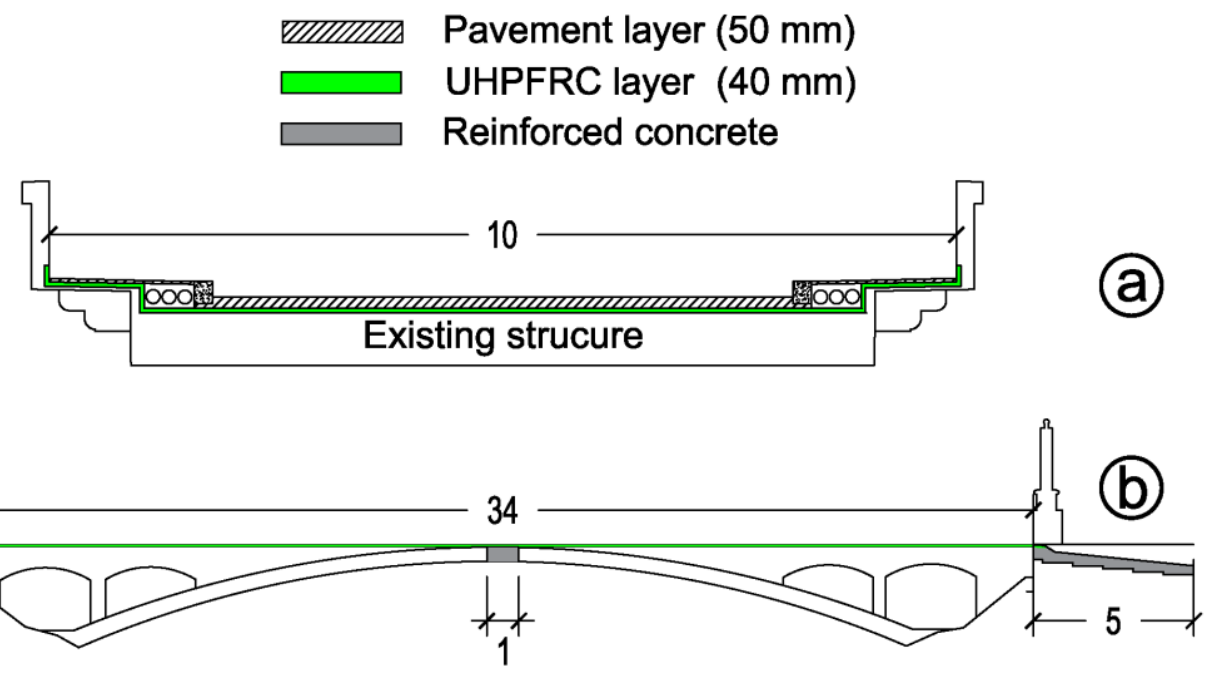

Figure 4. Cross section (a) and longitudinal cross-section (b) of the interventions using UHPFRC (all dimensions in $\mathrm{m})$, Methods 2 and 3.

(3) Method 3 is similar to Method 2, but uses PE-UHPFRC instead of S-UHPFRC.

The verification of the bridge after the interventions corresponding to strengthening (Methods 2 and 3) shows conformity factors with enough margin to accommodate traffic load models according to the standard applicable for new constructions (type II after SIA 261/1), corresponding to the verification in Method 1 [28].

Figure 5 presents the boundaries of the studied model, which take into account partial/full demolition and disposal of the existing structure as well as material production and transportation for renewal works. The same target service life of 100 years was considered for all methods. For maintenance, the asphalt pavement has to be replaced every 25 years for all methods. Moreover, in the case of Method 1, the waterproofing membrane, deteriorated concrete underneath the waterproofing membrane, and the whole of the curbs have to be changed every 50 years. On the contrary, because of the very low water permeability of UHPFRC, it is possible to avoid the waterproofing membrane in Methods 1 and 2. Furthermore, considering the much higher durability of the UHPFRC methods, no further concrete replacement is assumed to be needed. As the environmental impact of daily traffic does not depend on the construction scenarios and is largely dominant during the service life of a bridge [29], this effect was not considered when comparing the impact of the three different intervention methods.

The different steps for demolition and reconstruction with P-RC and strengthening with UHPFRC are presented in Tables 3 and 4, respectively. The transport distances for disposal, formworks, steel rebars, post-tensioning cables, ready-mix concrete, waterproofing membrane, and hot mix asphalt are also given in the same tables. It is assumed that the UHPFRC is prepared on site, using portable mixers. 


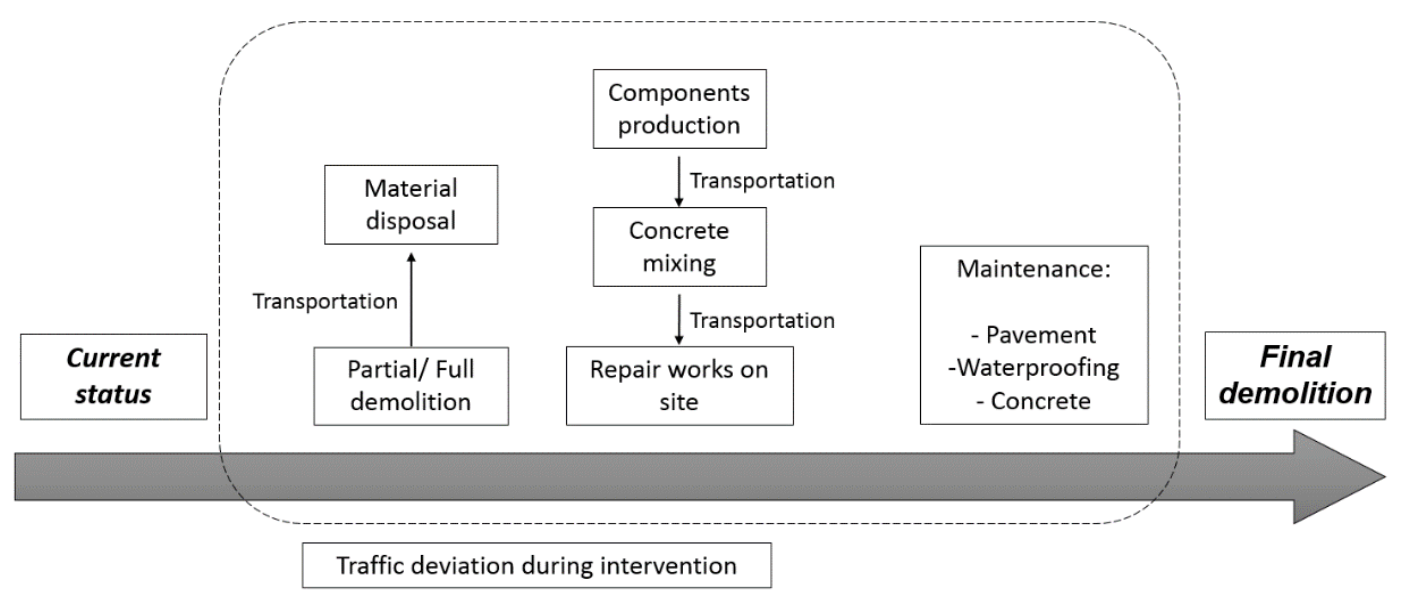

Figure 5. System boundaries for the restoration/renewal of the Guillermaux Bridge.

Table 3. Operations for demolition and reconstruction (Method 1).

\begin{tabular}{|c|c|c|c|}
\hline & Description & Quantity & Distance \\
\hline \multirow{6}{*}{ 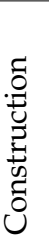 } & Demolition and disposal of the existing bridge & $360 \mathrm{~m}^{3}$ & $50 \mathrm{~km}$ \\
\hline & Formworks & $8.2 \mathrm{t}$ & $30 \mathrm{~km}$ \\
\hline & Reinforcing steel & $34.5 \mathrm{t}$ & $83 \mathrm{~km}$ \\
\hline & Post-tensioning cables & $7.8 \mathrm{t}$ & $83 \mathrm{~km}$ \\
\hline & Concrete for girders and slab & $237.6 \mathrm{~m}^{3}$ & $8 \mathrm{~km}$ \\
\hline & Waterproofing membrane & $340 \mathrm{~m}^{2}$ & $50 \mathrm{~km}$ \\
\hline \multirow{11}{*}{ 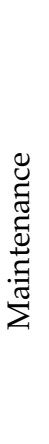 } & Asphalt pavement & $18.9 \mathrm{~m}^{3}$ & $51.7 \mathrm{~km}$ \\
\hline & Removal and disposal of pavement & $16 \mathrm{~m}^{3}$ & $50 \mathrm{~km}$ \\
\hline & New pavement & $16 \mathrm{~m}^{3}$ & $51.7 \mathrm{~km}$ \\
\hline & Removal and disposal of pavement & $18.9 \mathrm{~m}^{3}$ & $50 \mathrm{~km}$ \\
\hline & Removal and disposal of deteriorated concrete & $10 \mathrm{~m}^{3}$ & $50 \mathrm{~km}$ \\
\hline & Removal and disposal of waterproofing & $340 \mathrm{~m}^{2}$ & $50 \mathrm{~km}$ \\
\hline & New waterproofing & $340 \mathrm{~m}^{2}$ & $50 \mathrm{~km}$ \\
\hline & New concrete & $10 \mathrm{~m}^{3}$ & $8 \mathrm{~km}$ \\
\hline & New pavement & $18.9 \mathrm{~m}^{3}$ & $51.7 \mathrm{~km}$ \\
\hline & Removal and disposal of pavement & $16 \mathrm{~m}^{3}$ & $50 \mathrm{~km}$ \\
\hline & New pavement & $16 \mathrm{~m}^{3}$ & $51.7 \mathrm{~km}$ \\
\hline
\end{tabular}

Table 4. Operations for strengthening with steel (S)/PE-UHPFRC and rebar (Methods 2 and 3).

\begin{tabular}{|c|c|c|c|}
\hline & Description & Quantity & Distance \\
\hline \multirow{7}{*}{ 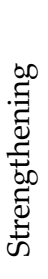 } & Removal and disposal of pavement & $18.9 \mathrm{~m}^{3}$ & $50 \mathrm{~km}$ \\
\hline & Removal and disposal of deteriorated concrete & $17 \mathrm{~m}^{3}$ & $50 \mathrm{~km}$ \\
\hline & High-pressure water jetting & $5 \mathrm{~h}$ & - \\
\hline & Reinforcing steel & $13.3 \mathrm{t}$ & $83 \mathrm{~km}$ \\
\hline & Concrete & $45 \mathrm{~m}^{3}$ & $8 \mathrm{~km}$ \\
\hline & S/PE-UHPFRC & $21.5 \mathrm{~m}^{3}$ & Per component \\
\hline & Gravel & $46 \mathrm{~m}^{3}$ & $98 \mathrm{~km}$ \\
\hline \multirow{7}{*}{ 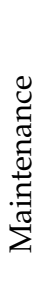 } & Asphalt pavement & $18.9 \mathrm{~m}^{3}$ & $51.7 \mathrm{~km}$ \\
\hline & Removal and disposal of pavement & $16 \mathrm{~m}^{3}$ & $50 \mathrm{~km}$ \\
\hline & New pavement & $16 \mathrm{~m}^{3}$ & $51.7 \mathrm{~km}$ \\
\hline & Removal and disposal of pavement & $16 \mathrm{~m}^{3}$ & $50 \mathrm{~km}$ \\
\hline & New pavement & $16 \mathrm{~m}^{3}$ & $51.7 \mathrm{~km}$ \\
\hline & Removal and disposal of pavement & $16 \mathrm{~m}^{3}$ & $50 \mathrm{~km}$ \\
\hline & New pavement & $16 \mathrm{~m}^{3}$ & $51.7 \mathrm{~km}$ \\
\hline
\end{tabular}


The mix proportions and amounts of concrete and UHPFRC materials that are needed for the different methods, as well as the transport distance of the different components (to ready-mix plant for concrete and to site for UHPFRC), are shown in Table 5, Table 6, and Table 7 for the P-RC, S-UHPFRC, and PE-UHPFRC methods, respectively. It should be noted that Method 2 was applied to the bridge deck in 2016 [26], and the UHPFRC used was the proprietary mix HOLCIM 707 [30]. As an approximation, the recipe of a closely related material of known composition (HIFCOM 13s) was used in this study, with a fiber dosage corresponding to that of HOLCIM H707.

Table 5. Material mix design for demolition and reconstruction with P-RC (Method 1).

\begin{tabular}{lclll}
\hline \multirow{2}{*}{ Material Components } & Distance $\mathbf{( k m )}$ & \multicolumn{2}{l}{ Mix Design $\mathbf{( k g / \mathbf { m } ^ { \mathbf { 3 } } )}$} & \multirow{2}{*}{ Total (kg) } \\
& & $\mathbf{C} 3 \mathbf{3} \mathbf{3 7}$ & $\mathbf{C 2 0 / 2 5}$ & \\
\hline CEM I 42.5 R & 41 & 350 & 280 & 80,010 \\
Water & - & 180 & 168 & 42,216 \\
Sand & 98 & 650 & 650 & 15,4375 \\
Gravel & 98 & 1200 & 1300 & 28,9450 \\
HRWRA & 30 & 5 & 1.5 & 1032 \\
\hline Total volume $\left(\mathrm{m}^{3}\right)$ & & 193 & 44.5 & \\
\hline
\end{tabular}

Table 6. Material mix design for S-UHPFRC (Method 2).

\begin{tabular}{|c|c|c|c|c|}
\hline \multirow{2}{*}{ Material Components } & \multirow{2}{*}{ Distance (km) } & \multicolumn{2}{|c|}{ Mix Design $\left(\mathrm{kg} / \mathrm{m}^{3}\right)$} & \multirow{2}{*}{ Total (kg) } \\
\hline & & S-UHPFRC & Concrete & \\
\hline CEM I 42.5 R & 41 & & 385 & 17,325 \\
\hline CEM III/B $32.5 \mathrm{~N}$ & 41 & 1277 & & 27,455 \\
\hline Silica fume (I) & 685 & 96 & & 2064 \\
\hline Fine quartz sand (I) & 550 & 643 & & 13,824 \\
\hline Sand & 98 & & 690 & 31,050 \\
\hline Gravel & 98 & & 1030 & 46,350 \\
\hline Water & - & 173 & 185 & 12,044 \\
\hline HRWRA & 30 & 42 & 4.9 & 1123 \\
\hline Steel fibers & $20,780^{1}$ & 298 & & 6,407 \\
\hline Total volume used & $\left(\mathrm{m}^{3}\right)$ & 21.5 & 45 & \\
\hline
\end{tabular}

Table 7. Material mix design for PE-UHPFRC (Method 3).

\begin{tabular}{|c|c|c|c|c|}
\hline \multirow{2}{*}{ Material Components } & \multirow{2}{*}{ Distance (km) } & \multicolumn{2}{|c|}{ Mix Design (kg/m³) } & \multirow{2}{*}{ Total $(\mathbf{k g})$} \\
\hline & & PE-UHPFRC & Concrete & \\
\hline CEM I $52.2 \mathrm{~N}$ & 410 & 508 & & 10,922 \\
\hline CEM I $42.5 \mathrm{R}$ & 41 & & 385 & 17,325 \\
\hline Silica fume & 482 & 178 & & 3827 \\
\hline Limestone filler & $698^{1}$ & 559 & & 12,018 \\
\hline Quartz powder & 144 & 223 & & 4794 \\
\hline Fine quartz sand & 336 & 525 & & 11,287 \\
\hline Sand & 98 & & 690 & 31,050 \\
\hline Gravel & 98 & & 1030 & 46,350 \\
\hline Water & - & 165 & 185 & 11,872 \\
\hline HRWRA & 30 & 27 & 4.9 & 801 \\
\hline PE fibers & $25,950^{2}$ & 19.6 & & 421.4 \\
\hline Total volume used & $\left(\mathrm{m}^{3}\right)$ & 21.5 & 45 & \\
\hline
\end{tabular}

${ }^{1} 112$ Truck + 586 Train. ${ }^{2} 150$ Truck + 1060 Train + 24,740 Ship.

Table 8 shows the production location, transport distance, and the transport type of the different components. 
Table 8. Transport distances $(\mathrm{km})$ of the different components.

\begin{tabular}{lllll}
\hline Component & Location & Truck & Train & Ship \\
\hline CEM I 52.5 N & Le Teil, France & 410 & & \\
CEM I 42.5 R & Eclépens, Switzerland & 41 & & \\
CEM III/B 32.5 N & Untervaz, Switzerland & 285 & & \\
Silica fume (I) & Pocking, Germany & 685 & & \\
Silica fume (II) & Le Pontet, France & 482 & & \\
Limestone fillers & Perpignan, France & 112 & 586 & \\
Quartz powder & Basel, Switzerland & 144 & & \\
Fine quartz sand (I) & Baumbach, Germany & 550 & & \\
Fine quartz sand (II) & Hostun, France & 336 & & \\
Sand and Gravel & Marin, Switzerland & 35 & & \\
HRWRA & Düdingen, Switzerland & 30 & & \\
Steel fibers & China & 150 & 2630 & 24,740 \\
PE fibers & Japan & 150 & 1060 & \\
Steel reinforcement & Gerlafingen, Switzerland & 83 & & \\
\hline
\end{tabular}

\subsection{Inventory Data and Impact Assessment}

The environmental impact of the different methods was investigated, considering three impact categories, with a time horizon of one hundred years: Global warming potential $\left(\mathrm{GWP}_{100}\right)$, which is expressed in $\mathrm{kg} \mathrm{CO}_{2 \text {-eq, }}$ cumulative energy demand (CED), which is expressed in MJ, and ecological scarcity (UBP), which is measured in a single weighted indicator by ecopoints and is the contribution of the processes on the overall environmental impacts, including toxicity.

The assessment methods used in this study are harmonized with the methods adopted by Koordinationskonferenz der Bau- und Liegenschaftsorgane der öffentlichen Bauherren (KBOB) [31], a well-established LCA dataset for construction products in Switzerland. The GWP $\mathrm{GW0}_{100}$ was assessed using the IPCC 2013 method [32] while the Cumulative Energy Demand 1.09 Method was considered for CED calculation [33]. Finally, the UBP indicator was calculated according to the Ecological Scarcity 2013 Method [34], an indicator particularly suitable for Switzerland as it employs eco-factors based on Swiss environmental targets and legislation.

Secondary data from Ecoinvent 3 [35]—currently the most reliable database for Swiss unit processes-were assumed for material processes, freight transportation, and energy and waste treatments, and SimaPro 8.5 was used as the software to model the processes [36]. The allocation at the point of substitution was considered as the most representative for process modeling, and data from the library "unit process" were adopted.

The environmental burdens from the production and transportation of components were considered and calculated with the original system boundaries of the Ecoinvent database. All the production processes not included in the Ecoinvent database, namely those for silica fume, HRWRA, steel fibers, and PE fibers, were modeled using secondary data from the literature [13,37-39]. As it was shown that the environmental loads from the transportation of the construction equipment to the site would be negligible $[27,40,41]$, this impact was not included in the investigation.

Two criteria were considered to define the system boundaries for product processing. The first considers the $2^{\text {nd }}$ order calculation depth, which includes materials used for processing, transport, and other operations. The second considers the cut-off method, which defines when a flow is no longer relevant to the system. Thus, by-products such as recycled materials or production residues are outside the system boundaries. All benefits and loads beyond the system boundaries, e.g., recycling potential, energy recovery, etc., were not taken into account. In the end of life (EoL) model, a landfill scenario was assumed for demolished materials. A process for onsite demolition, crushing, and disposal in an inert landfill was assumed for disposing of concrete, while a specific process for a sanitary landfill was assumed for the asphalt and waterproofing membrane. 


\section{Results and Discussion}

Three different levels of evaluation were investigated. In the first level, only the impact of component production on environmental burdens of the bridge intervention was considered. The second level considered the effect of all the steps that are needed for the intervention on the bridge including the impact of demolition works and transportation of the components and materials. Finally, the third level investigated the environmental impact of the bridge through its lifetime, considering the required maintenance works.

As a first step of the environmental analysis, a comparison based on the impacts of material processing for the interventions was carried out, and the results are shown in Figure 6. In this figure, the results were normalized based on those for Method 1, and $100 \%$ stands for $151.3 \mathrm{tCO}_{2 \text { eq }}, 1505.8 \mathrm{GJ}$, and 264.6 MPt in the GWP, CED, and UBP categories, respectively. The reinforcement (steel rebars and tendons), steel fibers, and cement accounted for the highest impact at this scale. In the CED category, the production of the asphalt pavement was responsible for approximately $7 \%$ of the overall impact.

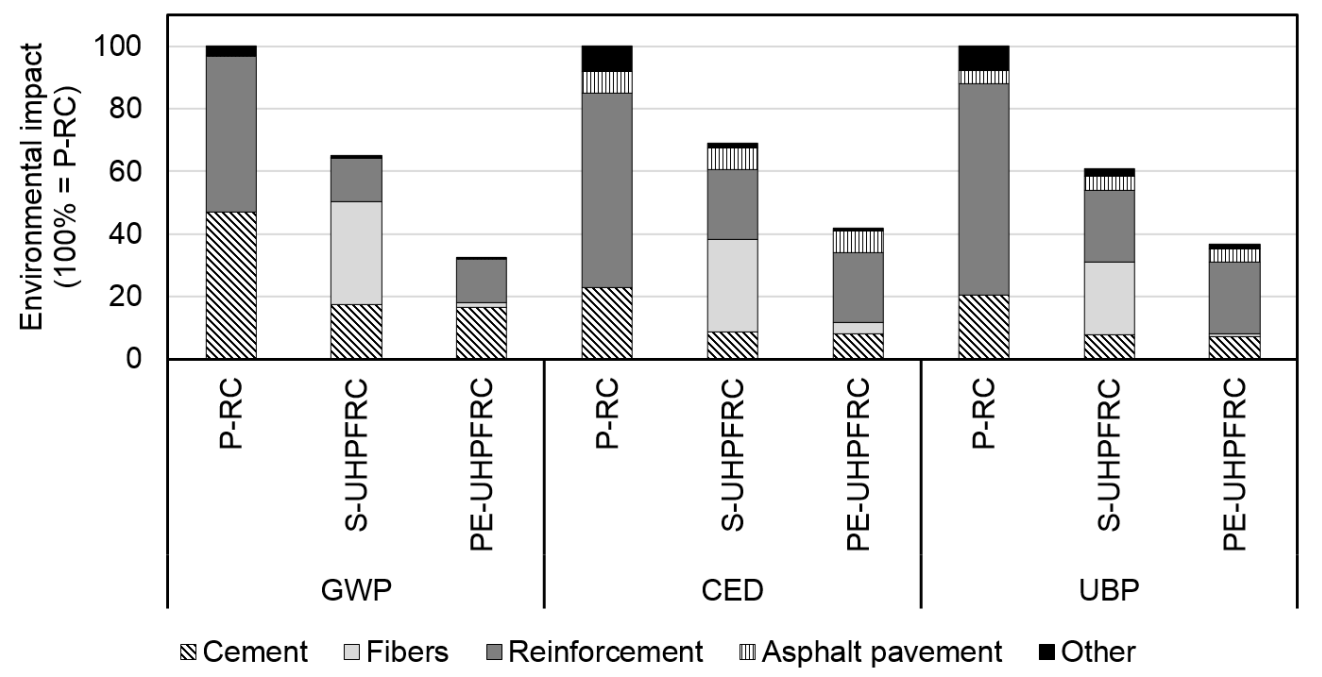

Figure 6. Normalized environmental impact at the structure scale (only materials). (GWP: global warming potential, CED: cumulative energy demand, and UBP: ecological scarcity)

Although it was not considered in this study, in the case of the PE-UHPFRC method, it would be possible to avoid the bituminous pavement and process the PE-UHPFRC surface to achieve an integral pavement with sufficient skid resistance, which could pave the way to additional reductions in the environmental impact. Furthermore, the rebars accounted for approximately $50 \%$ of the environmental impact in the PE-UHPFRC method, which indicates the greater potential of this material to decrease even more the environmental impact for rehabilitation applications without reinforcement compared with that of methods using P-RC or S-UHPFRC.

Figure 7 presents the LCA results of the restoration of the bridge, normalized based on those for Method 1 with P-RC. Considering the whole process of restoration, production of the components has the largest influence on the environmental impact, while transportation is responsible for almost $10 \%$ of the total impact.

Figure 8 shows the total environmental impact of the different methods over the lifetime of the bridge (100 years), according to the three different categories of environmental indices. The use of UHPFRC results in a reduced environmental impact of the bridge intervention in all cases. The GWP decreases by $40 \%$ and $70 \%$ by using S-UHPFRC and PE-UHPFRC, respectively. Furthermore, a similar trend is achieved for CED and UBP. 


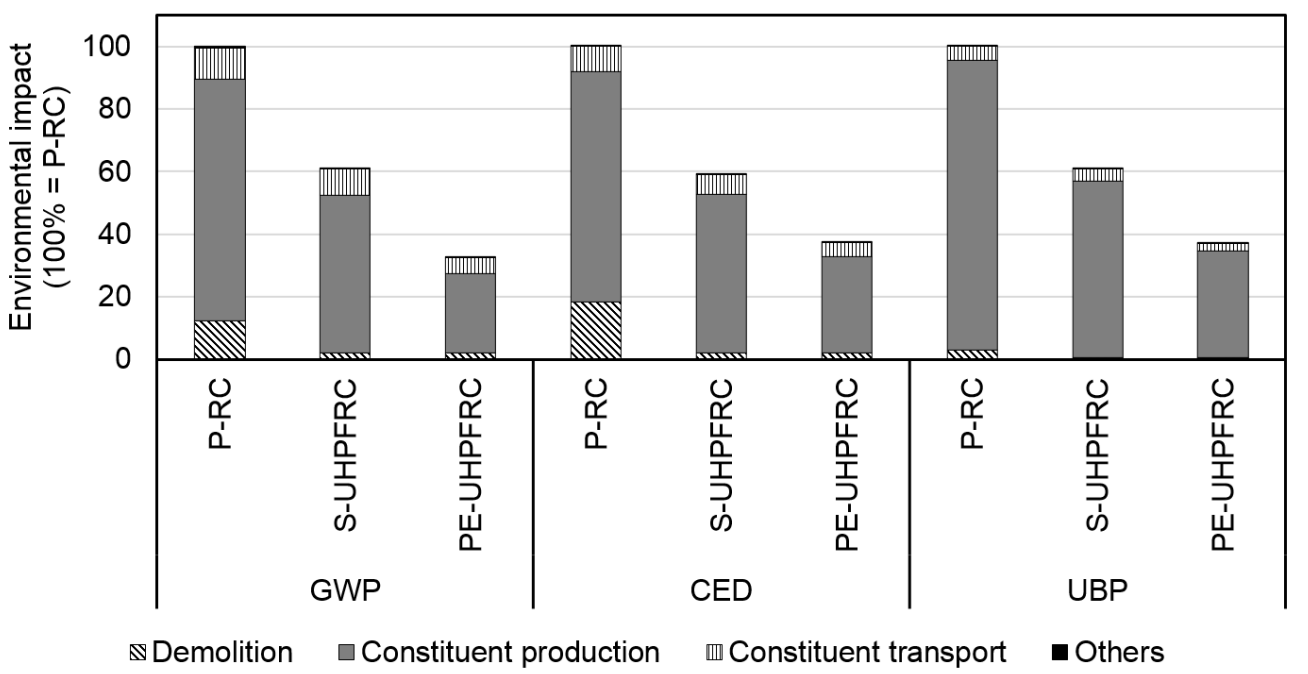

Figure 7. Normalized environmental impact at the scale of the structure (without maintenance).

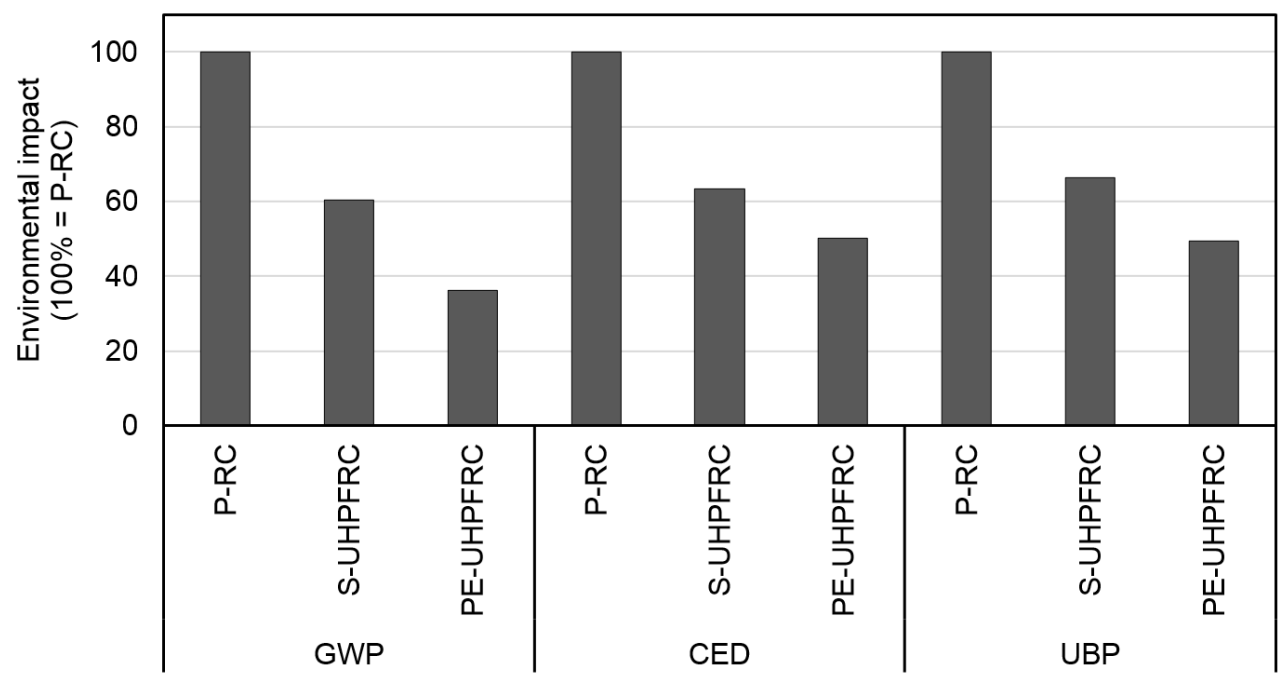

Figure 8. Normalized environmental impact over the life cycle of 100 years.

It should be noted that the environmental effect of traffic deviation during the site works was not accounted for in this study. However, Habert et al. [13] showed that taking traffic deviation into account is beneficial for UHPFRC methods as the duration of site works for a P-RC method is almost three times more than that for a method using UHPFRC.

\section{Conclusions}

- A novel structural UHPFRC with synthetic fibers was introduced for rehabilitation and strengthening of existing structures.

- The LCA showed a 55\% and 29\% decrease in the environmental impact of the strengthening method using PE-UHPFRC compared with that of replacement with a new bridge, and of the conventional UHPFRC method for restoration of a $34 \mathrm{~m}$ span road bridge, respectively. This highlights the strong potential of PE-UHPFRC in reducing the environmental impact of construction sites.

- This reduction will be even more pronounced for rehabilitation applications without rebar (pure protective function of the UHPFRC overlay). 
- The reinforcement (steel rebars and tendons), steel fibers, and cement accounted for the highest environmental impact among the material components.

- The production and casting of the asphalt pavement is responsible for approximately $7 \%$ of the cumulative energy demand of all methods. The possibility of avoiding the asphalt pavement in the PE-UHPFRC method opens up the possibility of additional reductions in the environmental impact of rehabilitation/strengthening sites and simplification of the associated construction works.

Author Contributions: Conceptualization, E.D.; methodology, E.D., G.H.; validation, E.D.; formal analysis, A.H., F.P.; investigation, A.H.; data curation, A.H., F.P.; writing—original draft preparation, A.H., F.P.; writing-review and editing, A.H., F.P.; visualization, A.H., F.P.; supervision, E.D., G.H.; project administration, E.D., G.H.; funding acquisition, E.D., G.H.

Acknowledgments: This project was financially supported by the Swiss National Science Foundation (grant 407040_154063/1) through the National Research Program "Energy Turnaround" (NRP 70). The authors would like to gratefully acknowledge Dyneema (Hans Plug), Omya (Pascal Gonnon), LafargeHolcim (Catherine Chambouleyron), and Sika (Patrick Stähli) for donating the PE fibers, limestone filler, cement, and superplasticizer, respectively. Finally, the authors would like to thank Serge Despont and Gilles Guignet, technicians at GIS/EPFL, and Mohamed Abdul Hafiz (MCS/EPFL) for their help regarding the preparation of test setups and performing the tests.

Conflicts of Interest: The authors declare no conflict of interest.

\section{References}

1. Solomon, S.; Qin, D.; Manning, M.; Averyt, K.; Marquis, M. Climate Change 2007-The Physical Science Basis: Working group I Contribution to the Fourth Assessment Report of the IPCC. 4; Cambridge University Press: Cambridge, UK, 2007.

2. Corvalan, C.; Hales, S.; McMichael, A. Ecosystems and human well-being. In Millennium Ecosystem Assessment; Island Press: Washington, DC, USA, 2005.

3. Stern, N. The Economics of Climate Change: The Stern Review; Cambridge University Press: Cambridge, UK, 2007.

4. Brundtland, G.H.; Khalid, M.; Agnelli, S.; Al-Athel, S. Our common future. In Report of the World Commission on Environment and Development; Oxford University Press: Oxford, UK, 1987.

5. Cuche, A.; Gozzer, D.; Linder, L.; Tschäppeler, S.; Chassot, J.M.; Hars, E.; Folly, M.; Haas, H.; Wyss, M. Rapport Sur L'état du Réseau des Routes Nationales; OFROU: Ittigen, Switzerland, 2016; p. 14.

6. Buitelaar, P. Ultra high performance concrete: Developments and applications during 25 years. In Proceedings of the Plenary Session International Symposium on Ultra High Performance Concrete, Kassel, Germany, 13-15 September 2004.

7. Denarié, E.; Brühwiler, E. Cast-on site UHPFRC for improvement of existing structures-achievements over the last 10 years in practice and research. In Proceedings of the 7th Workshop on High Performance Fiber Reinforced Cement Composites, Stuttgart, Germany, 1-3 June 2015.

8. Brühwiler, E.; Denarié, E. Rehabilitation and strengthening of concrete structures using ultra-high performance fibre reinforced concrete. Struct. Eng. Int. 2013, 23, 450-457. [CrossRef]

9. Brühwiler, E.; Bastien Masse, M. Strengthening the Chillon viaducts deck slabs with reinforced UHPFRC. In Proceedings of the IABSE Conference 'Structural Engineering: Providing Solutions to Global Challenges', Geneva, Switzerland, 23-25 September 2015; pp. 1171-1178.

10. Denarié, E. ARCHES D06: Recommendations for the tailoring of UHPFRC recipes for rehabilitation. In European Project 6th FWP/ARCHES Assessment and Rehabilitation of Central European Highway Structures, WP 5-'Harden Structures to last with UHPFRC'; MCS/EU PP: Lausanne, Switzerland; Brussels, Belgium, 2009.

11. Denarié, E.; Habert, G.; Šajna, A. ARCHES D14-Recommendations for the use of UHPFRC in composite structural members-rehabilitation Log Čezsoški bridge. In European Project 6 th FWP/ARCHES Assessment and Rehabilitation of Central European Highway Structures, WP 5-'Harden Structures to last with UHPFRC'; MCS/EU PP: Lausanne, Switzerland; Brussels, Belgium, 2009.

12. Denarié, E.; Brühwiler, E. Strain-hardening ultra-high performance fibre reinforced concrete: Deformability versus strength optimization. Restor. Build. Monum. 2011, 17, 397-410. [CrossRef] 
13. Habert, G.; Denarié, E.; Šajna, A.; Rossi, P. Lowering the global warming impact of bridge rehabilitations by using Ultra High Performance Fibre Reinforced Concretes. Cem. Concr. Compos. 2013, 38, 1-11. [CrossRef]

14. Stengel, T.; Schießl, P. Life cycle assessment (LCA) of ultra high performance concrete (UHPC) structures. In Eco-Efficient Construction and Building Materials; Pacheco-Torgal, F., Cabeza, L.F., Labrincha, J., de Magalhães, A., Eds.; Woodhead Publishing: Shaston, UK; Cambridge, UK, 2014; pp. 528-564.

15. Stengel, T.; Schießl, P. Sustainable construction with UHPC-from life cycle inventory data collection to environmental impact assessment. In Proceedings of the 2nd International Symposium on Ultra High Performance Concrete, Kassel, Germany, 5-7 March 2008; Kassel University Press: Kassel, Germany, 2008; pp. 461-468.

16. Hajiesmaeili, A.; Denarie, E. Next Generation UHPFRC for Sustainable Structural Applications; ACI Special Publication: Farmington Hills, MI, USA, 2018; p. 326.

17. Fava, J.A. Will the next 10 years be as productive in advancing life cycle approaches as the last 15 years? Int. J. Life Cycle Assess. 2006, 11, 6-8. [CrossRef]

18. Asif, M.; Muneer, T.; Kelley, R. Life cycle assessment: A case study of a dwelling home in Scotland. Build. Environ. 2007, 42, 1391-1394. [CrossRef]

19. Bouhaya, L.; Le Roy, R.; Feraille-Fresnet, A. Simplified environmental study on innovative bridge structure. Environ. Sci. Technol. 2009, 43, 2066-2071. [CrossRef] [PubMed]

20. Ortiz, O.; Castells, F.; Sonnemann, G. Sustainability in the construction industry: A review of recent developments based on LCA. Constr. Build. Mater. 2009, 23, 28-39. [CrossRef]

21. Hajiesmaeili, A.; Denarié, E. Capillary flow in UHPFRC with synthetic fibers, under high tensile stresses. Cem. Concr. Res. 2019. under review.

22. SIA 2052. Béton Fibré Ultra-Performant (BFUP): Matériaux, Dimensionnement et Exécution; Cahier Technique; Swiss Society of Engineers and Architects: Zürich, Switzerland, 2017.

23. BS EN 13057:2002. Determination of Resistance of Capillary Absorption; British Standards Institution: London, $\mathrm{UK}, 2002$.

24. ASTM. ASTM C1437-15. Standard Test Method for Flow of Hydraulic Cement Mortar; ASTM International: West Conshohocken, PA, USA, 2015.

25. ISO 14040. Environmental Management: Life Cycle Assessment, Principles and Framework; International Organization for Standardization: Geneva, Switzerland, 2006.

26. Brühwiler, E.; Schiltz, P. Le BFUP Pour Ajouter de la Plus-Value aux Ouvrages en Béton Armé. TRACÉS 02. 2018, pp. 6-10. Available online: http://www.sollertia.ch/wp-content/uploads/2018/02/bfup.pdf (accessed on 3 December 2019).

27. Kawai, K.; Sugiyama, T.; Kobayashi, K.; Sano, S. Inventory data and case studies for environmental performance evaluation of concrete structure construction. J. Adv. Concr. Technol. 2005, 3, 435-456. [CrossRef]

28. Loraux, C.; Denarié, E. Vérification de la Sécurité Structurale du Pont de Guillermaux à L'état Actuel et Après la Rénovation; In Rapport n MCS 23.13.07-1; MCS: Lausanne, Switzerland, 2014.

29. Beuving, E.; De Jonghe, T.; Goos, D.; Lindahl, T.; Stawiarski, A. Environmental impacts and fuel efficiency of road pavements. Eur. Roads Rev. 2004, 2, 30-36.

30. HOLCIM. Béton Fibré à Ultra Haute Performances-Produits et Applications; Holcim: Untervaz, Switzerland, 2011.

31. KBOB. Betonsortenrechner: Switzerland, 2019. Available online: http://treeze.ch/fileadmin/user_upload/ calculators/551-Betonsortenrechner_Planer.htm (accessed on 3 December 2019).

32. Krey, V.; Masera, O.; Blanforde, G.; Bruckner, T.; Cooke, R.; Fish-Vanden, K.; Haberl, H.; Hertwich, E.; Kriegler, E.; Müller, D.; et al. Annex II: Metrics \& methodology ed O Edenhofer et al. In Climate Change 2014: Mitigation of Climate Change, Contribution of Working Group III to the Fifth Assessment Report of the Intergovernmental Panel on Climate Change; Cambridge University Press: Cambridge, UK, 2014; pp. 1281-1328.

33. Hischier, R.; Weidema, B.P.; Althaus, H.J.; Bauer, C.; Dóka, G.; Dones, R.; Frischknecht, R.; Hellweg, S.; Humbert, S.; Jungbluth, N.; et al. Implementation of Life Cycle Impact Assessment Methods; Swiss Centre for Life Cycle Inventories: Dubendorf, Switzerland, 2010; p. 176.

34. Frischknecht, R.; Knöpfel, S.B. Ecological scarcity 2013-New features and its application in industry and administration—54th LCA forum, Ittigen/Berne, Switzerland, December 5, 2013. Int. J. Life Cycle Assess. 2014, 19, 1361-1366. [CrossRef] 
35. Wernet, G.; Bauer, C.; Steubing, B.; Reinhard, J.; Moreno-Ruiz, E.; Weidema, B. The ecoinvent database version 3 (part I): Overview and methodology. Int. J. Life Cycle Assess. 2016, 21, 1218-1230. [CrossRef]

36. PRé Consultants. What's New in SimaPro 8.3; PRé Consultants: Amersfoort, The Netherlands, 2016.

37. Häner, A.; Schluep, M.; Gälli, R. Mass flow and risk analysis of modern superplasticisers. In Proceedings of the ORGAGEC Symposium, Nantes, France, 4-5 October 2005.

38. Chen, C. Une Étude des Bétons de Construction Classiques et Alternatifs par la Méthode D’analyse du Cycle de vie. 2009. Available online: https://www.semanticscholar.org/paper/Une-\%C3\%A9tude-des-b\%C3\%A9tonsde-construction-classiques-et-Chen/c0aa01404ad1f457d57728de15d84a2ff0a2439b\#paper-header (accessed on 4 December 2019).

39. Cicala, G.; Lo Faro, C. Material Selection: Polymeric Composites Matrix. In Wiley Encyclopedia of Composites; Wiley: Hoboken, NJ, USA, 2011; pp. 1-38.

40. Ventura, A.; Mazri, C.; Monéron, P.; Jullien, A.; Schemid, M. Environmental comparison of pavement binding courses recycled at varying rates by means of the Life Cycle Analysis method. Bull. Lab. Ponts Chaussées 2004, 250, 251.

41. Xing, S.; Xu, Z.; Jun, G. Inventory analysis of LCA on steel-and concrete-construction office buildings. Energy Build. 2008, 40, 1188-1193. [CrossRef]

(C) 2019 by the authors. Licensee MDPI, Basel, Switzerland. This article is an open access article distributed under the terms and conditions of the Creative Commons Attribution (CC BY) license (http://creativecommons.org/licenses/by/4.0/). 